\title{
Máscaras cirúrgicas em tempos de coronavírus
}

\author{
Amanda Gonçalves Franco ${ }^{1}$ \\ Aline Batista Gonçalves Franco ${ }^{2}$ \\ Geraldo Alberto Pinheiro de Carvalho ${ }^{2}$ \\ Elimário Venturin Ramos² \\ Sérgio Candido Dias ${ }^{2}$
}

Desde que foram registrados os primeiros contágios, a infecção pelo coronavírus (Covid-19) se deu de maneira bastante rápida e, em poucas semanas, passou a ser considerada uma pandemia, uma doença disseminada por vários países. Conforme os casos aumentaram e com eles o número de mortes, alguns itens, que até então eram ignorados por grande parte da nossa população, ganharam notoriedade.

A Anvisa, Agência Nacional de Vigilância Sanitária, caracteriza esses itens como Equipamento de Proteção Individual (EPI's). Com o surto do coronavírus, os itens que mais ganharam destaque no combate da doença foram as máscaras cirúrgicas. São máscaras usadas por profissionais da saúde durante as cirurgias, que começaram a ser utilizadas pela população da Espanha em 1919 no surto de epidemia da gripe Espanhola e que voltara agora como destaque na prevenção do Covid-19. Ela precisa ser confeccionada de material tecido-não tecido (TNT), deve possuir no mínimo uma camada interna e outra externa e obrigatoriamente, um elemento filtrante. A camada externa e o elemento filtrante, para serem eficientes, devem ser resistentes à penetração de fluidos transportados pelo ar. Além disso tudo, ela precisa cobrir a área do nariz e boca e ter um ajuste adequado do contorno do nariz e das bochechas.
O coronavírus ou, como muitos o designam, Covid-19, é um vírus cuja transmissão acontece através de contato próximo, seja por meio de gotículas de saliva ou por toque em superfícies contaminadas. Portanto, vale ressaltar assim a necessidade do uso das máscaras cirúrgicas como forma de prevenção desse contágio. Seu uso pode ser público, ou seja, a sua utilização não precisa ser necessariamente apenas dos profissionais que apresentarem contato com os pacientes portadores do vírus. Sendo assim, as máscaras cirúrgicas podem ser usadas também pelas pessoas que apresentam os sintomas comuns de uma infecção respiratória (febre, tosse, espirros e dificuldade para respirar), para que não ocorra a transmissão do vírus, caso o mesmo esteja presente. Uma outra indicação é para os indivíduos que ficam no mesmo cômodo de alguém com confirmação da enfermidade, assim como para o enfermo.

De acordo com a Organização Mundial da Saúde (OMS), alguns protocolos devem ser seguidos a fim de se utilizarem as máscaras de maneira correta. Antes de usálas, as mãos devem ser lavadas com agua e sabão, ou com o próprio álcool em gel, encontrados nas farmácias e redes de supermercado. No momento em que forem colocadas, deve-se cobrir a boca e o nariz e certificar-se de que não há espaços entre o rosto e o acessório. É necessário

\footnotetext{
$\overline{{ }^{1} \text { Universidade de Itaúna, Faculdade }}$ de Odontologia. Itaúna, MG, Brasil.

${ }^{2}$ Faculdade São Leopoldo Mandic, Curso de Odontologia. Rua José Rocha Junqueira, 13, Swift, 13045-755, Campinas, SP, Brasil Correspondência

para / Correspondence to: ABG FRANCO. E-mail: <aalinebgfranco@yahoo.com>.

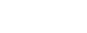

Como citar este artigo / How to cite this article

Franco AG, Franco ABG, Carvalho GAP, Ramos EV, Dias SC. Máscaras cirúrgicas em tempos de coronavírusr. InterAm J Med Health 2020;3:e202003003. 
também que o usuário evite colocar as mãos na máscara durante o uso e no momento que sentir certa umidade, deve-se trocar por uma nova, retirando a máscara por trás e jogando a mesma em uma lixeira fechada, para que não ocorra a possibilidade da contaminação. Além disso, a OMS não recomenda o uso das máscaras de tecido, dando ênfase sempre para as descartáveis.

No entanto, no caso de os profissionais da área de saúde atuarem em procedimentos com possibilidade de geração de aerosol em pacientes suspeitos ou infectado, apenas a máscara cirúrgica não garante 100\% de eficácia na prevenção contra o coronavírus. Nesse caso recomenda-se o uso das chamadas máscaras de proteção respiratória. Estas devem ser ajustadas corretamente e o modo de uso, manipulação e armazenamento da mesma variam e devem ser seguidos conforme as recomendações do fabricante. E, assim como as máscaras cirúrgicas, as máscaras de proteção respiratória devem ser utilizadas seguindo as recomendações dadas pela Anvisa e OMS.

Dessa maneira, diante de um surto epidêmico viral no mundo, como estamos vivendo nesses tempos de coronavírus, podemos ver a importância dos métodos preventivos quando se trata de minimizar as transmissões do vírus. As máscaras cirúrgicas e de proteção respiratória cirúrgica vem desempenhando um papel importante no controle da disseminação desse microrganismo novo no mundo e foram consideradas um excelente e acessível método para isso. Contudo, deve-se lembrar que, mesmo utilizando uma máscara, a manutenção da distância do paciente (mais de 1 metro) é particularmente importante para reduzir o risco de transmissão.

\section{REFERÊNCIAS}

Brasil. Ministério da Saúde. Agência Nacional de Vigilância Sanitária. Resolução RDC n. 05, de 21 de março de 2020. Orientações para a prevenção e o controle de infecções pelo novo coronavírus (sars-cov-2) em instituições de longa permanência para idosos (ILPI) [online]. Disponível em: <http://portal.anvisa.gov.br/documents/33852/271858/ nota+t \%c3\% 89cnica+n\%c2 \%ba+05-2020+gvimsggtes-anvisa+-+orienta $\% c 3 \% 87 \%$ c3\%95es+para+a+p reven \%c3\% 87\%c3\%83o+e+o+controle+de+infec\%c3 $\% 87 \%$ c3\% $\% 5$ es+pelo+novo+coronav \%c3\% 8drus+em +institui \%c3\%87\%c3\%95es+de+longa+perman \%c3\% 8ancia+para+idosos\%28ilpi\%29/8dcf5820-fe26-49ddadf9-1 cee4e6d3096>.
Giraldi G. Coronavírus já está em 50 países e OMS eleva para 'muito alto' o risco [online]. Cidade: São Paulo; 2020 [citado 2020 Fev 28]. Disponível em: $<$ https://saude.estadao.com.br/noticias/geral, passamde-83-mil-os-casos-de-coronavirus-confirmados-nomundo,70003213743>.

Manarini T. Máscaras cirúrgicas para coronavírus: quem deve usar, quando e como? [online]. Cidade: São Paulo; 2020 [citado 2020 March 21]. Disponível em: <https:// saude.abril.com.br/medicina/mascaras-cirurgicas-paracoronavirus-quem-deve-usar-quando-e-como/>.

Sanches D. Uso de máscaras cirúrgicas pode proteger contra o coronavírus? [online]. Cidade: São Paulo; 2020 [citado 2020 Fev 26]. Disponível em: <https://www.uol. com.br/vivabem/noticias/redacao/2020/02/26/uso-demascaras-cirurgicas-pode-proteger-contra-o-coronavirus. htm>.

Sponchiato D. Como o coronavírus é transmitido e por quanto tempo ele resiste por aí [online]. Cidade: São Paulo; 2020 [citado 2020 March 24]. Disponível em: <https:// saude.abril.com. br/medicina/como-o-coronavirus-etransmitido-e-por-quanto-tempo-ele-resiste-por-ai/>. 